\title{
Assessment of the nasolabial angle in young Brazilian black subjects with normal occlusion
}

\section{Verificação do ângulo nasolabial em jovens brasileiros melanodermas com oclusão normal}

\author{
Maria Beatriz Borges de Araújo Magnani* \\ Darcy Flávio Nouer** \\ Paulo Roberto Aranha Nouer*** \\ João Sarmento Pereira Neto* \\ Ivana Uglik Garbui**** \\ Eloísa Marcantonio Böeck ${ }^{* * * *}$
}

\begin{abstract}
Black individuals present craniofacial characteristics which differ from those of other races, especially the white race, whose cephalometric analyses are usually considered as the standard in routine orthodontic diagnosis and treatment planning. Further studies are therefore needed to enable more accurate and specific diagnoses for this ethnic group. The present study was conducted in order to assess average values for the nasolabial angle in young Brazilian black individuals with normal occlusion, and to assess the occurence of sexual dimorphism. Thirty-six lateral skull, extraoral radiographs from Brazilian black individuals were selected from the archives of the Scientific Recordings Department, Orthodontics Graduate Program, School of Dentistry of Piracicaba, State University of Campinas (UNICAMP). The patients' ages varied from 10 to 14 years, they presented normal occlusion upon clinical examination, and had not been submitted to orthodontic treatment. The cephalometric landmarks from which the nasolabial angle was obtained and measured were traced by a single researcher. Statistical analysis and evaluation of the results led to the conclusion that the nasolabial angle of young Brazilian black individuals is sharper, i.e., the soft tissue profile is more protruded. The average value for the whole sample was $88.14^{\circ} \pm 12.52^{\circ}$. The nasolabial angle was statistically smaller among females $(\mathrm{p}<0.05)$, demonstrating the occurrence of sexual dimorphism.
\end{abstract}

DESCRIPTORS: Cephalometry; Dental occlusion; Orthodontics; African continental ancestry group; Nasolabial angle.

\begin{abstract}
RESUMO: Os individuos melanodermas possuem caracteristicas craniofaciais diferentes das apresentadas pelas demais raças, principalmente por leucodermas que, normalmente, são considerados como padrão nas análises cefalométricas utilizadas rotineiramente no diagnóstico e planejamento dos tratamentos ortodônticos. São, portanto, necessárias novas pesquisas que permitam um diagnóstico mais acurado e específico para esse grupo étnico. Os pesquisadores desenvolveram esta pesquisa com o objetivo de verificar valores médios do ângulo nasolabial em jovens melanodermas brasileiros com oclusão clinicamente normal e de verificar a ocorrência de dimorfismo sexual. Foram selecionadas 36 telerradiografias de cabeça, tomadas em norma lateral, de indivíduos brasileiros melanodermas, na faixa etária de 10 a 14 anos, de ambos os sexos, com oclusão clinicamente normal e que nunca se submeteram a tratamento ortodôntico, provenientes dos arquivos do Setor de Documentação Científica do Curso de Pós-Graduação em Ortodontia da Faculdade de Odontologia de Piracicaba da Universidade Estadual de Campinas. Sobre essas radiografias foram delimitados os pontos e as linhas que dão origem ao ângulo nasolabial, o qual foi traçado e medido por um único pesquisador. Após análise estatística e avaliação dos resultados, concluiu-se que o ângulo nasolabial em individuos jovens brasileiros melanodermas apresenta-se mais agudo, ou seja, o perfil tegumentar apresenta-se mais protruso. Os valor médio obtido para a amostra toda foi $88,14^{\circ} \pm 12,52^{\circ}$. O ângulo nasolabial foi estatisticamente menor no sexo feminino $(\mathrm{p}<0,05)$, demonstrando a existência de dimorfismo sexual.
\end{abstract}

DESCRITORES: Cefalometria; Oclusão dentária; Ortodontia; Grupo ancestral do continente africano; Ângulo nasolabial.

* Assistant Professors, PhDs; **Chairman, Professor of Orthodontics; ****Doctorate Students - Department of Pediatric Dentistry, Orthodontics Area, School of Dentistry of Piracicaba, State University of Campinas.

*** PhD, Coordinating Professor of the Master's Course in Orthodontics, São Leopoldo Mandic Dentistry Research Center. 
Magnani MBBA, Nouer DF, Nouer PRA, Pereira Neto JS, Garbui IU, Böeck EM. Assessment of the nasolabial angle in young Brazilian black subjects with normal occlusion. Braz Oral Res 2004;18(3):233-7.

\section{INTRODUCTION}

The related literature has demonstrated that skeletal, dental and facial profile differences exist when subjects from distinct ethnic groups are compared. Thus, each group should be evaluated differently, considering their racial characteristics, in order to produce better diagnoses and treatment planning.

Investigations comparing ethnic groups have shown that the cranial and soft tissue dimensions of African descendents are different from those of whites. Cotton et al. ${ }^{6}$ (1951) observed that black subjects had a facial convexity angle larger than that of whites. As for the soft tissue profile, it was demonstrated that black subjects' faces are wider, their mouths are larger and wider, and their noses are flatter as compared to whites ${ }^{23}$. Alte$\operatorname{mus}^{2,3}(1968,1963)$ compared the soft tissue profile of black and white children of both genders. He observed that the facial profile of black children was more protruded. The anterior position of the maxilla and upper lip in African-American subjects were discoveries of Drummond ${ }^{7}$ (1968); Fonseca, Klein ${ }^{10}$ (1978), and Alexander, Hitchcock ${ }^{1}$ (1978). Jacobson, Oosthuizen ${ }^{13}$ (1970) also observed the same anterior relationship of the maxilla in South African black subjects. In Brazil, Magnani, Sakima $^{14}$ (1981) detected a higher facial prognathism in a group of black subjects with excellent occlusion.

The improvement of facial aesthetics has been one of the main objectives of orthodontic treatment. However, criteria for evaluation seem to be influenced only by the individual aesthetic concept of the professional.

Studies on facial profile have demonstrated that facial balance should have been obtained if a proportional relationship between nose, upper lip and chin exists ${ }^{4,11,12}$. Thus, the nasolabial angle became a clinical and cephalometric parameter for the determination of soft tissue profile alterations, and it is related to the anteroposterior position of the maxilla ${ }^{21}$. Capelozza ${ }^{5}$ (1989) showed that the nasolabial angle indicates the actual sagittal position of the maxilla, thus being considered of great clinical importance.

Owen ${ }^{18}(1984)$ reported that an arbitrary value for the nasolabial angle adopted by plastic surgeons and orthodontists ranged from $90^{\circ}$ to $110^{\circ}$. However, McNamara Jr. ${ }^{15}$ (1984) and McNamara, Brudon $^{16}$ (1993) used the nasolabial angle in their cephalometric evaluations and observed a value of $102^{\circ} \pm 8^{\circ}$. The nasolabial angle, given by the relationship between the upper lip and columella nasi, has great importance even when isolated of other soft tissue points. Fitzgerald et al. ${ }^{9}$ (1992) found a mean value of $114^{\circ} \pm 10^{\circ}$ in young white adults, and Scheideman et al. ${ }^{20}$ (1980) found a mean value of $111.04^{\circ}$.

In order to evaluate the clinical application of the nasolabial angle in orthodontic diagnosis and treatment planning, Silva Filho et al. ${ }^{21}$ (1990) found an angle of $104^{\circ} \pm 11,50^{\circ}$ in white individuals with normal occlusion, without sexual dimorphism. In addition, it was observed that craniofacial growth did not alter the nasolabial angle significantly. Prahl-Andersen et al. ${ }^{19}$ (1995) observed a small decrease in the value of the nasolabial angle with age, but with subsequent stabilization of this value in adolescence.

Siqueira et al. ${ }^{22}$ (2003) studied the changes of the nasolabial angle as a result of deviations in the upper incisors position induced by craniofacial growth. It was concluded that facial and dental alterations that occurred during the craniofacial growth in Brazilian white youths did not influence the nasolabial angle significantly.

The nasolabial angle is representative of the soft tissue profile and remains an excellent clinical and cephalometric parameter to reveal the anteroposterior position of the maxilla and consequently to establish the treatment planning of dental and skeletal malocclusions ${ }^{8}$, thus the concern among authors in assessing the contour of the soft tissue profile as well as in understanding the modifications that happen in this facial profile as a consequence of growth.

Taking into account the different ethnic groups, the objective of the present study was to determine the mean value of the nasolabial angle in a group of Brazilian black subjects of both genders.

\section{MATERIAL AND METHOD}

The following protocol (number 042/2003) was approved by the Ethical Committee in Research, School of Dentistry of Piracicaba, State University of Campinas, and is in agreement with the Resolution 196/96 of the National Committee of Health, Ministry of Health, Brazil.

The sample examined in the present study was made of 36 lateral cephalometric radiographs of the head belonging to the files of the Section of Scientific Documentation of the Orthodontics Mas- 
Magnani MBBA, Nouer DF, Nouer PRA, Pereira Neto JS, Garbui IU, Böeck EM. Assessment of the nasolabial angle in young Brazilian black subjects with normal occlusion. Braz Oral Res 2004;18(3):233-7.

ter's Degree Course, School of Dentistry of Piracicaba, State University of Campinas. The selected radiographs were obtained from Brazilian black subjects residing in Piracicaba city, with ages of 10 to 14 years, of both genders, with normal occlusion and that had never undergone orthodontic treatment.

The lateral radiographs were divided in two groups according to gender (male or female). In a dark room, a single operator drew the cephalograms using the following materials: a transparency viewer; "ultraphan" paper with the standard size of $17.5 \times 17.5 \mathrm{~cm}$ and $0.07 \mathrm{~mm}$ of thickness; a $0.3 \mathrm{~mm}$ pencil case; a transparent ruler with $0.5 \mathrm{~mm}$ subdivisions; a protractor with an approach of 0.1 degree; a template; adhesive tape. The intra-examinator error did not exceed 3\%; according to Midtgard et al. ${ }^{17}$ (1974), this means that the applied method of measuring was appropriate.

The anatomical structures of the skull and face were delimited, and lines and planes were drawn to obtain the cephalometric landmarks used in the study.

The following cephalometric landmarks were used: pronasal point (Prn), on the anterior nasal apex; subnasal point (Sn), in the middle of the inferior border on the anterior nasal aperture; and upper lip (Ls), the most anterior point on the vermilion of the upper lip (Figure 1).

A cephalogram with the variables used in the present study can be seen in Figure 1.

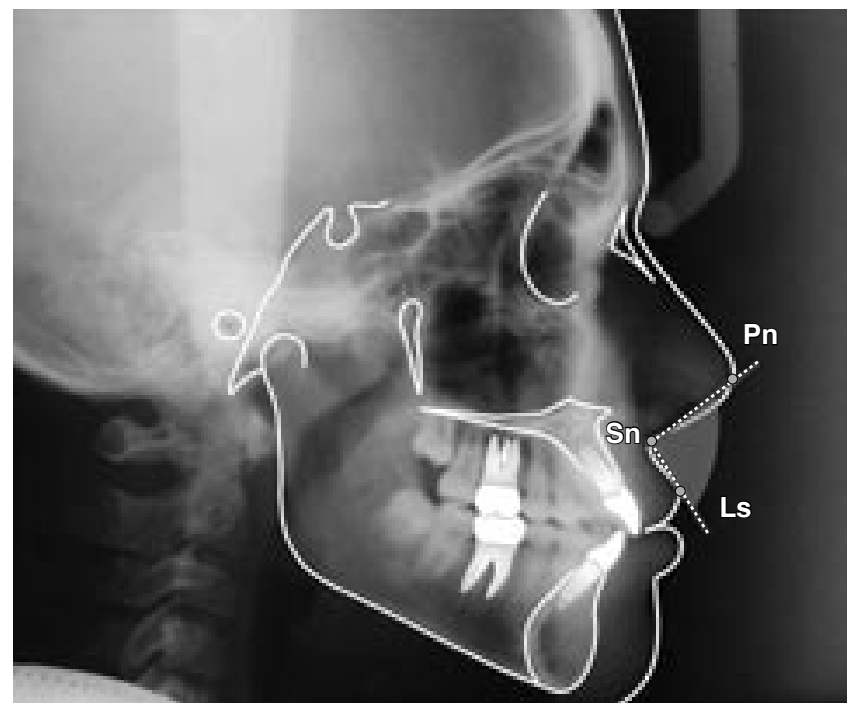

FIGURE 1 - Landmarks used for measurements of the nasolabial angle. Prn: pronasal point; Sn: subnasal point; Ls: upper lip.
Student's $t$ test analysis and a significance level of $5 \%$ were applied to determine averages, standard deviation, and minimum and maximum values of the nasolabial angle, as well as to support an evaluation of sexual dimorphism.

\section{RESULTS}

As we can observe in Table 1 and Graph 1 , the mean value of the nasolabial angle for the total sample of Brazilian black subjects, was $88.14^{\circ}$ with a standard deviation of $12.52^{\circ}$. For females the mean value was $85.05^{\circ}$ with a standard deviation of $11.93^{\circ}$; for males the average was $92^{\circ}$ with a standard deviation of $12.52^{\circ}$. The nasolabial angle was significantly smaller $(\mathrm{p}<0.05)$ in females.

\section{DISCUSSION}

Orthodontic diagnosis should not be accomplished based solely on hard tissue information since changes in dental positions cause alterations in the facial profile. Modern orthodontics adds elements of facial analysis to the diagnosis effort.

Holdaway $^{11,12}$ (1983, 1984) stated that the orthodontic treatment plan should include the perspectives of orthodontic alterations based on soft tissue analysis, taking into account the soft tissue profile.

The nasolabial angle is an important auxiliary parameter in the diagnosis of anteroposterior maxillary discrepancies, and is a strategic area of the composition of facial profiles. As a consequence, the clinical application of this angle contributes to the differential diagnosis of skeletal malocclusions, particularly of Class II malocclusions. Burstone 4 (1958) defined the nasolabial angle as representative of maxillary inclination, suggesting that when this variable is increased it reflects a maxillary

TABLE 1 - Means, standard deviations (SD), minimum (Min.) and maximum (Max.) values of the nasolabial angle.

\begin{tabular}{l|c|c|c}
\hline \hline \multirow{2}{*}{} & \multicolumn{2}{|c|}{ Gender } & \multirow{2}{*}{ Total sample } \\
\cline { 2 - 3 } & Females & Males & \\
\hline Mean & $85.05^{\circ} \mathrm{B}$ & $92.00^{\circ} \mathrm{A}$ & $88.14^{\circ}$ \\
\hline SD & $11.93^{\circ}$ & $12.52^{\circ}$ & $12.52^{\circ}$ \\
\hline Min. & $64.00^{\circ}$ & $70.00^{\circ}$ & $64.00^{\circ}$ \\
\hline Max. & $113.00^{\circ}$ & $113.00^{\circ}$ & $113.00^{\circ}$ \\
\hline \hline
\end{tabular}

Means with different letters are significantly different at $\mathrm{p}<0.05$. 
Magnani MBBA, Nouer DF, Nouer PRA, Pereira Neto JS, Garbui IU, Böeck EM. Assessment of the nasolabial angle in young Brazilian black subjects with normal occlusion. Braz Oral Res 2004;18(3):233-7.

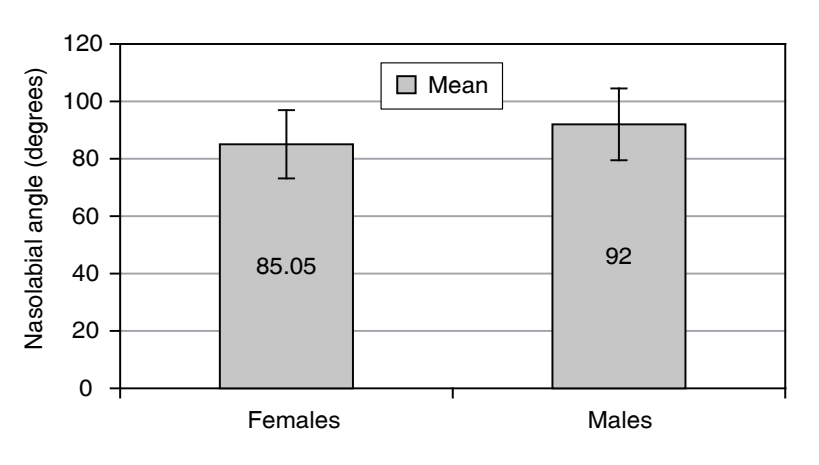

GRAPH 1 - Mean value of the nasolabial angle in males and females.

retrusion, and when decreased, a maxillary protrusion.

The related literature indicates that the value of the nasolabial angle related to harmonious faces varies considerably. Among the cited values are $114.08^{\circ} \pm 9.58^{\circ 9} ; 102^{\circ 15,16} ; 105^{\circ} \pm 8^{\circ 18} ; 111.04^{\circ 20}$; $104^{\circ} \pm 11.5^{\circ 21}$ and from $108.76^{\circ}$ to $114.40^{\circ 22}$.

The mean value observed in our study was $88.14^{\circ}$, which is smaller than that reported by authors referred in studies accomplished with white individuals. However, as our sample was composed of young black subjects, the observed nasolabial angle was smaller, suggesting that this ethnic group presents a more biprotruded profile and a reduced interincisive angle, which is in agreement with others studies ${ }^{1,2,3,6,7,10,13,14}$, whose authors compared white and black subjects.

\section{REFERENCES}

1. Alexander TL, Hitchcock HP. Cephalometric standards for American negro children. Am J Orthod 1978;74:298304.

2. Altemus LA. Cephalofacial relationships. Angle Orthod 1968;38:175-84.

3. Altemus LA. Comparative integumental relationships. Angle Orthod 1963;33:217-21.

4. Burstone CJ. The integumental profile. Am J Orthod 1958;44:1-25.

5. Capelozza L, de Araujo Almeida G, Mazzottini R, Cardoso Neto J. Maxillomandibular relationships in patients with dentofacial deformities: diagnostic criteria utilizing three cephalometric analyses. Int J Adult Orthodon Orthognath Surg 1989;4:13-26.

6. Cotton WN, Takano WS, Wong WMW. The Downs analysis applied to three other ethnic groups. Angle Orthod 1951;21:213-20.
As can be observed in Table 1, the nasolabial angle presented variation according to gender; in females it was significantly smaller, confirming the existence of sexual dimorphism. This result differs from those of Silva Filho et al. ${ }^{21}$ (1990) and Fitzgerald et al..$^{9}$ (1992), who found that black individuals showed similar angular and linear measurements in both groups, male and female.

According to Prahl-Andersen et al. ${ }^{19}$ (1995) the tendency of the nasolabial angle is to decrease with age, specially until adolescence, when the growth of nose, chin and lips is expressed more intensely. Some studies have demonstrated that soft tissues that vary in thickness are the main factor in the determination of full facial profile $e^{4,12,15,21}$.

\section{CONCLUSION}

Based on the obtained results, it was concluded that the mean value of the nasolabial angle found in our sample of Brazilian black youths was $88.14^{\circ} \pm 12.52^{\circ}$, which is in agreement with others studies. The smaller value of the nasolabial angle suggests that black individuals present a more protruded profile and a reduced interincisive angle.

The value of the nasolabial angle was significantly smaller $(p<0.05)$ in females, characterizing sexual dimorphism.

Since one of the objectives of orthodontic treatment is to achieve facial aesthetics, specific soft tissue measures which respect the facial pattern of each race should be considered during the diagnosis phase.

7. Drummond RA. A determination of cephalometric norms for the negro race. Am J Orthod 1968;54:670-82.

8. Elias AC. The importance of the nasolabial angle in the diagnosis and treatment of malocclusion. Int $\mathrm{J}$ Orthod 1980;18:7-12.

9. Fitzgerald JP, Nanda RS, Currier GF. An evaluation of the nasolabial angle and the relative inclinations of the nose and upper lip. Am J Orthod Dentofacial Orthop 1992;102:328-34.

10. Fonseca RJ, Klein WD. A cephalometric evaluation of American negro women. Am J Orthod 1978;73:152-60.

11. Holdaway R. A soft tissue cephalometric analysis and its use in orthodontic treatment planning. Part I. Am J Orthod 1983;84:1-28

12. Holdaway R. A soft tissue cephalometric analysis and its use in orthodontic treatment planning. Part II. Am J Orthod 1984;85:279-93. 
Magnani MBBA, Nouer DF, Nouer PRA, Pereira Neto JS, Garbui IU, Böeck EM. Assessment of the nasolabial angle in young Brazilian black subjects with normal occlusion. Braz Oral Res 2004;18(3):233-7.

13. Jacobson A, Oosthuizen L. The craniofacial skeletal pattern of the South African Bantu. J Dent Assoc S Afr 1970;25:361-5.

14. Magnani MBBA, Sakima T. Comparação cefalométrica entre negróides e caucasóides. RGO 1981;37:225-8.

15. McNamara Jr JA. A method of cephalometric evaluation. Am J Orthod 1984;86(6):449-69.

16. McNamara Jr JA, Brudon WL. Orthodontic and orthopedic treatment in mixed dentition. Ann Arbor: Needham Press; 1993. 365 p.

17. Midtgard J, Bjork G, Linder Aronson S. Reproducibility of cephalometric landmarks and errors of measurements of cephalometric cranial distances. Angle Orthod 1974;44(1):56-67.

18. Owen $\mathrm{AH} 3^{\text {rd }}$. Diagnostic block cephalometrics. Part I. J Clin Orthod 1984;18:400-22.

19. Prahl-Andersen B, Ligthelm-Bakker ASWMR, Wattel E, Nanda R. Adolescent growth changes in soft tissue profile. Am J Orthod Dentofacial Orthop 1995;107:476-83.
20. Scheideman GB, Bell WH, Legan HL, Finn RA, Reisch JS. Cephalometric analysis of dentofacial normals. Am J Orthod 1980;78:405-20.

21. Silva Filho OG, Okada T, Tocci LFC. Avaliação cefalométrica do ângulo nasolabial aos 7 anos, 12 anos e 19 anos, numa amostra de oclusão normal. Rev SBO 1990;1:108-13.

22. Siqueira VCV, Canuto CE, Scavone Junior $\mathrm{H}$, Negreiros PE. O relacionamento dos ângulos nasolabial e dos incisivos superiores com o plano palatino durante a fase do "patinho feio". Rev Dent Press Ortod Ortop Facial 2003;8(6):31-42.

23. Todd TW, Lindalla A. Dimensions of the body: whites and American negroes of both sexes. Am J Phys Anthropol 1928;7:35-101.

Received for publication on Oct 17, 2003 Sent for alterations on Feb 27, 2004 Accepted for publication on May 31, 2004 